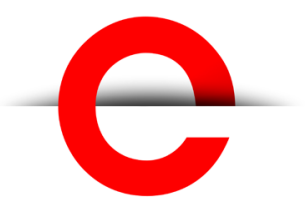

U T S

e PRESS
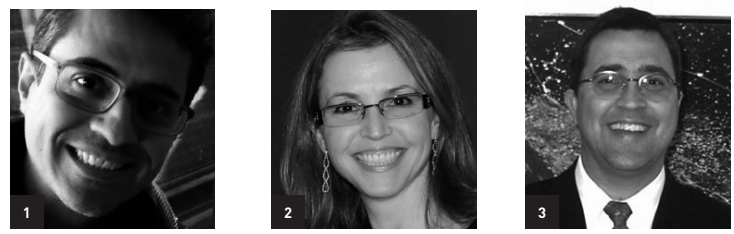

Project Management

Research and

Practice

Vol. 3

July-Dec. 2016
RESEARCH ARTICLE

\section{A Project Portfolio Management model adapted to non-profit organizations}

\author{
Fabrício Martins Lacerda', Cristina Dai Prá Martens², Henrique Mello Rodrigues \\ de Freitas ${ }^{3}$ \\ Management Graduate Program, UNINOVE - Universidade Nove de Julho, São Paulo, Brazil.
}

Corresponding author: Cristina Dai Prá Martens, Professor, Management Graduate Program, UNINOVE - Universidade Nove de Julho, São Paulo, Brazil. cristinadpmartenslagmail.com

DOI: http://dx.doi.org/10.5130/pmrp.v3i0.5120

\section{SYNOPSIS}

As they strive toward greater professionalism in carrying out their activities, nonprofit organizations have begun paying attention to project management. The nonprofit sector has also begun to adopt strategic planning techniques, making the acceptance of project portfolio management methodology a natural consequence. This article aims to propose a project portfolio management model adapted to the context of nonprofit organizations.

\section{RESEARCH DESIGN}

As research strategy we used the exploratory case study approach, adopting qualitative analysis. The data was collected through participant observation, document analysis, and in-depth interviews. In order to treat and triangulate the data, we applied the general strategy of case description and the analytical technique of pattern-matching. A project portfolio management conceptual model was proposed, based on the literature, with the following dimensions: strategic alignment, resources definition, project classification, project evaluation, project selection and prioritization, portfolio control, and resources allocation. We used this initial conceptual model to compare and analyze the procedures adopted in the case studied.

\section{RELEVANCE FOR PRACTICE AND EDUCATION}

In practical terms, the final proposed model includes elements that could be used as drivers for project portfolio management practices, as well as for developing strategy, mission, vision, and objectives in nonprofit organizations.
Published by UTS ePRESS | http://pmrp.epress.lib.uts. edu.au
DECLARATION OF CONFLICTING INTEREST The author(s) declared no potential conflicts of interest with respect to the research, authorship, and/or publication of this article. FUNDING This research had financial support from Brazilian institutions: CNPq - National Council for Scientific and Technological Development, CAPES Coordination for the Improvement of Higher Education Personnel, and FAP/UNINOVE. 
U T S

e PRES S

\section{MAIN FINDINGS}

Empiric analysis of the initial conceptual model allowed us to verify the applicability of the dimensions and suggest new elements, words, and nomenclatures, revealing an additional dimension called fund-raising. The model developed from the literature evolved into a proposed new model adapted to the context studied, comprising seven dimensions, six of which originated in the literature and one in the organizational practices identified by the study.

\section{Keywords}

\author{
Project Portfolio Management, Project Management, Nonprofit Organizations, Third \\ Sector
}

Type

Empirical

\section{Introduction}

Despite the peculiarities inherent in the management models employed by for-profitoriented organizations, they can be relevant to the management of the emerging nonprofit sector (Heinzen, Rossetto \& Altoff 2013). Academic efforts have come to understand the management characteristics and needs of organizations that compose the nonprofit sector (Golini, Kalchsmidt \& Landoni 2015; Heinzen, Rossetto \& Altoff 2013; Fischer \& Mendonça 2002; Soares \& Melo 2010), that is, nonprofit organizations (NPOs).

NPOs have become interested in project management, insofar as many of them act through projects. However, the difficulty of interaction among scholars of the social field and authors of the project management methodology (Ruggeri 2011), apparently due to an incompatibility of visions, concepts, and cultures (Unger, Rank \& Gemünden 2015), can contribute to the nondevelopment of this relationship. Antunes, Loos \& Miguel (2012, p. 58) have pointed out that "the implementation of a portfolio management process is a difficult task in an organization, both conceptually and operationally."

Although the project portfolio management (PPM) knowledge area has been explored (Unger, Rank \& Gemünden 2015; Antunes, Loos \& Michael 2012; Castro \& Carvalho 2010a; Rabechini, Maximiano \& Martins 2005), an analysis of PPM models identified in the literature led us to conclude that they have not been developed or replicated in NPOs. Thus, the need arose to verify the applicability of these models within the context of these organizations, even if only one of the identified models has applicability to the nonprofit sector.

Within this context is the Brazilian Medical Association (BMA), which promotes projects for the study, discussion, improvement, and dissemination of issues around scientific and ethical standards, relating to the 53 nonprofit medical specialties recognized in Brazil. By definition, associations are groups of people gathered in defense of common interests (Corrion 2000). Projects carried out by the BMA focus on the training and professionalization of physicians, as well as on social issues and public health policies, among others. Many BMA projects depend on private and public financial resources.

This study aimed to investigate PPM practices for NPOs, given that studies under this approach are considered incipient, especially in the BMA. It seeks to answer the following 
U T S

e P R E S S research question: how can an NPO best manage its project portfolio? It has the objective of proposing a PPM conceptual model adapted to the context of NPOs. The results present a model that includes the PPM dimensions applicable to the sector. This study contributes to the knowledge of portfolio management practices in organizations, collaborating to meeting the application gap of PPM in NPOs (Rocha et al. 2009; Ruggeri 2011).

Following this introduction, subsequent sections discuss the literature on the subject and the research method, and then present an analysis of results, important situations for the model proposition, and closing remarks.

\section{Literature review}

This section describes conceptual aspects of project management systems suited to the nonprofit context, and then discusses PPM and its dimensions.

\section{Management systems in NPOs}

Management in the nonprofit sector is a strategic issue related to efficient operation and effective performance in accomplishing missions and goals (Moxham 2014; Machado, Francisconi \& Chaerki 2007; Albuquerque 2006). In this sense, Falconer (1999) identified four dimensions needed to develop management that can be generalized to the sector as a whole: stakeholder accountability, sustainability, service quality, and articulation capacity. Among these dimensions we emphasize stakeholder accountability, which refers to the organization's need for transparency and accountability in rendering accounts to its various stakeholders that hold a legitimate interest (Moxham 2014; Falconer 1999).

There is also a need for greater professionalization of fund-raising activities, so that the NPOs can compete, avoid a decline in resources, and meet the requirements for project approval (Santos et al. 2008). For these authors, the relationship with sponsors and partners should also be enhanced, and projects should be carried out with consideration of the interest of the funding body, while maintaining a relationship with the organization's mission.

However, even with multiple funding sources, many projects planned by NPOs are not carried out; they are rejected by financing institutions due to lack of specificity regarding the objectives, impacts, activities, results, and benefits of the project (Santos et al. 2008).

A study developed by Borges \& Costa Filho (2010) points out that NPOs have shown receptiveness to the new dynamics of management, guided by efficiency and focus on timely results. The authors also state that the adoption of a model is not just a strategic tool for these organizations, but a condition of existence and survival. Because their function is of public interest, it is important that NPOs cultivate transparency regarding their project portfolio (Marcovitch 1997), as well as results achieved and resources allocated (Kaplan 2001; Marcovitch 1997), which further enhance the effective and transparent implementation of their resources (Moxham 2014; Oliveira, Ross \& Altimeyer 2005). In this sense, the following discussion considers PPM and dimensions related to the operational, tactical, and strategic levels of organizations.

\section{Project and project portfolio management}

The concept of projects has evolved over time (Antunes, Loos \& Miguel 2012). Today, a project is defined as a temporary endeavor and a process undertaken to reach a specific purpose under the constraints of time, budget, and other resources (Project Management Institute, or 
PMI, 2008; Kerzner 2006). The focus of project management is relatively new, being applicable to any timely initiative related to a specific goal.

Recent years have seen a rapid growth and acceptance of project management (Kerzner 2006; Antunes, Loos \& Miguel 2012), and the tools, methodologies, and management approaches that make up the discipline have been applied to different areas, different purposes, and different cultures (PMI 2008; Ruggeri 2011). More and more organizations are embracing project management, mainly as a means to better planning (Kerzner 2006; Ruggeri 2011).

PMI-Rio's methodology (PMI - Rio de Janeiro 2008), the standard for project management in the nonprofit sector, proposes five steps for planning and managing a project: project proposal, fund-raising, project execution, project monitoring and control, and project closure. The fund-raising step, divided into the processes of planning fund-raising, conducting fund-raising, and signing agreement(s) with investor(s), makes clear the adaptation of the methodology for organizations in the nonprofit sector.

Project-oriented organizations must be careful to define the type and number of projects they can perform with available resources, which has led to the adoption of PPM methodology (Kerzner 2006). PPM covers different stages of decision, so projects that add value to an organization can be selected, prioritized, and balanced (Unger, Rank \& Gemünden 2015; Padovani, Carvalho \& Muscat 2010). It is a continuous process of decision-making to select and keep the best initiatives (project mix), and carry out projects that are strategically aligned with the organization's goals (Unger, Rank \& Gemünden 2015; Gutiérrez \& Magnusson 2014; Almeida \& Almeida 2013).

Antunes, Loos \& Miguel (2012, p. 67) point out that, "the successful implementation of the portfolio management model depends on the choice of project selection criteria. Each organization should define the importance of each criterion to its business despite the standard criteria extant in the literature." In the conceptual framework proposed by Castro \& Carvalho (2010b), the PPM activities are related to seven dimensions (Figure 1).

In Figure 1, the strategic alignment dimension is highlighted as being implied in the conceptual framework. Next, we approach each PPM dimension, based on the study by Castro \& Carvalho (2010b).

\section{Strategic alignment dimension}

When aligned with the organization's strategies, a project portfolio contributes to the achievement of strategic goals and objectives (Rabechini, Maximiano \& Martins 2005; Rocha et al. 2009). The definition of the decision criteria that will be used for decision-making may vary according to the type of project and type of organization (Castro \& Carvalho 2010a). Knowledge of business models, strategic elements, and project evaluation methodology is important in order to frame the projects and evaluate them properly (Rabechini, Maximiano \& Martins 2005).

\section{Resources definition dimension}

This dimension seeks to select the number of projects, considering the resources available, and may use methods that enable analysis and balance between resource capacity and project demands (De Maio, Verganti \& Corso 1994; Archer \& Ghasemzadeh 1999; Cooper, Edgett \& Kleinschmidt 2001; Castro \& Carvalho 2010a). The aim is to minimize the error of committing to projects with limited availability of human, financial, and material resources (Kerzner 2006). 
U T S

e PRES S

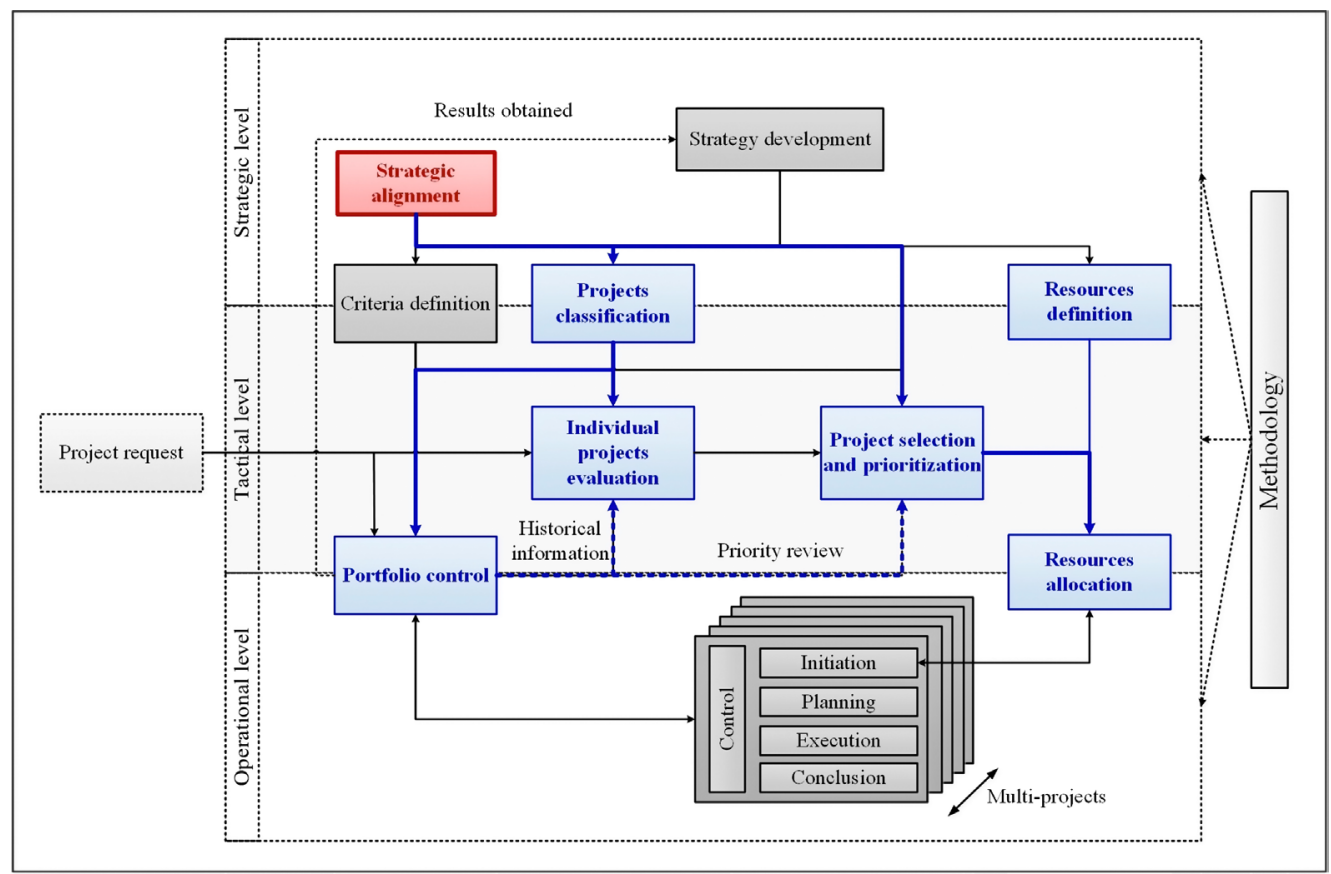

Figure 1 Dimensions of PPM

Source: adapted from Castro \& Carvalho (2010b)

\section{Project classification dimension}

Organizations can classify their projects in different ways (Castro \& Carvalho 2010a). Projects must be grouped into categories according to their relevance to the business so that filters or criteria can be applied for evaluation, selection, prioritization, and balancing of the portfolio (PMI 2008; Rocha et al. 2009; Castro \& Carvalho 2010a).

\section{Project evaluation dimension}

The use of project evaluation techniques depends on the needs of each organization, and may involve evaluating different attributes (Castro \& Carvalho 2010a). In this dimension, a prioritized list of projects is established (Rabechini, Maximiano \& Martins 2005). Some researchers add to this dimension, citing the criteria of qualitative and quantitative analysis to assist decision-making around strategic adequacy (Ghasemzadeh \& Archer 1999; Rabechini, Maximian \& Martin 2005; Kerzner 2006; Rocha et al. 2009; Castro \& Carvalho 2010a).

\section{Project selection and prioritization dimension}

This aims at a balanced project portfolio, considering the mission, vision, and strategy of the organization (Cooper, Edgett \& Kleinschmidt 2001; PMI 2008; Rocha et al. 2009). It prioritizes the projects in an orderly manner in each strategic or financial category, and establishes an organizational focus (PMI 2008; Rabechini, Maximiano \& Martins 2005). Projects must be compared with each other, and their priority defined by their importance and strategic contribution (Cooper, Edgett \& Kleinschmidt 2001; Rocha et al. 2009; Castro \& Carvalho 2010a). The involvement of senior management is critical (Kerzner 2006). 
U T S

e PRES S

\section{Portfolio control dimension}

This seeks to periodically monitor, control, and review the portfolio to ensure alignment of projects with organizational strategy, as well as with available resources, in an efficient manner (De Maio, Verganti \& Corso 1994; Archer \& Ghasemzadeh 1999; Rabechini, Maximiano \& Martins 2005; PMI 2008). Portfolio management also contributes to the use of different project control tools (Rabechini, Maximiano \& Martins 2005; Castro \& Carvalho 2010a).

\section{Resources allocation dimension}

Several projects share the same resources, and the matrix allocation of resources has become common practice (Castro \& Carvalho 2010a). Resources allocation enables the creation of a portfolio management plan, which includes developing rules for adding new projects, as these will join the competition for the organization's resources (Rabechini, Maximiano \& Martins 2005). Strategy and resources allocation should be closely linked (Cooper, Edgett \& Kleinschmidt 2001).

The relationship of these seven dimensions with operational, tactical, and strategic levels means the dimensions can be applied to various organizational contexts, whether for purposes of profit or other ends, such as those of the public and nonprofit sectors. In the case of NPOs, the seven PPM dimensions (Heinzen, Rossetto \& Altoff 2013; Rocha et al. 2009) can provide the necessary clarifications, and the establishment of agreements and consensus reached by adopting open communication and decentralized execution of activities (Fischer \& Mendonça 2002), without losing strategic focus on performance, transparency, mission, and social objectives (Gutiérrez \& Magnusson 2014; Moxham 2014; Smith \& Melo 2010).

\section{Conceptual model for studying PPM in organizations}

The literature review conducted for this study allowed us to identify eight conceptual models of PPM (De Maio, Verganti \& Corso 1994; Archer \& Ghasemzadeh 1999; Cooper, Edgett \& Kleinschmidt 2001; Rabechini, Maximiano \& Martins 2005; Kerzner 2006; PMI 2008; Rocha et al. 2009; Castro \& Carvalho 2010a). The models were selected according to their availability in the literature, scope, and notoriety.

Analysis of these models revealed that only the one proposed by Rocha et al. (2009) presents adaptation characteristics for the nonprofit sector. However, this model is directed to organizations that fund projects, not to those that execute them, highlighting a gap in the literature on PPM models applicable to a large portion of NPOs. In general, the other models are all directed to the context of for-profit economic organizations.

To perform a comparative analysis of the models it was necessary to define standardized dimensions, and we adopted those used by Castro \& Carvalho (2010b): strategic alignment, resources definition, project classification, project evaluation, project selection and prioritization, portfolio control, and resources allocation. Finally, the models were analyzed and compared in terms of common dimensions (implicit, explicit, or not foreseen), thus providing a foundation for consolidating the PPM conceptual model, consisting of elements proposed by the authors of the models in each of the seven dimensions, as shown in Table 1.

Table 1 was used as a conceptual model of PPM in conducting the empirical study, forming the basis of the script for the semi-structured interviews. The method and research techniques used in this study are presented next. 
Table 1 PPM conceptual model

\begin{tabular}{|c|c|}
\hline $\begin{array}{c}\text { PPM } \\
\text { DIMENSIONS }\end{array}$ & ELEMENTS \\
\hline $\begin{array}{l}\text { Strategic } \\
\text { Alignment }\end{array}$ & $\begin{array}{l}\text { 1) strategy definition as a pre-condition; 2) strategic } \\
\text { roadmap; 3) portfolio matrix; 4) strategic planning; 5) } \\
\text { weighted criteria for categorization; 6) Top management } \\
\text { participation; 7) visibility (image). }\end{array}$ \\
\hline $\begin{array}{l}\text { Resources } \\
\text { Definition }\end{array}$ & $\begin{array}{l}\text { 1) knowledge of available resources; 2) participation } \\
\text { of executives and managers in the definition of the } \\
\text { resources capacity. }\end{array}$ \\
\hline $\begin{array}{l}\text { Projects } \\
\text { Classification }\end{array}$ & $\begin{array}{l}\text { 1) limitation of available resources under consideration; } \\
\text { 2) project categories created; } 3 \text { ) projects and ideas } \\
\text { identified through brainstorming and surveys (market, } \\
\text { customers, suppliers and literature). }\end{array}$ \\
\hline $\begin{array}{l}\text { Projects } \\
\text { Evaluation }\end{array}$ & $\begin{array}{l}\text { 1) relevance and risk assessment; } 2 \text { ) adhesion to } \\
\text { strategic focus; 3) feasibility study; 4) criteria definition; } \\
\text { 5) quantitative analysis criteria (ROI, NPV, IRR, ECV, DCF, } \\
\text { decision tree); 6) Productivity rate; 7) qualitative analysis } \\
\text { criteria (technical, costs, term, quality, safety, legality and } \\
\text { economic); 8) scoring models, 9) alignment with the third } \\
\text { sector; 10) market survey. }\end{array}$ \\
\hline $\begin{array}{l}\text { Project } \\
\text { Selection and } \\
\text { Prioritization }\end{array}$ & $\begin{array}{l}\text { 1) observation of complex interaction between projects } \\
\text { for selection; 2) ad hoc selection techniques; } 3 \text { ) } \\
\text { scoring models; 4) AHP method; 5) sensibility matrix } \\
\text { and analysis; 6) operationalization of mission, vision } \\
\text { and strategy; 7) commercial success probability; } 8 \text { ) } \\
\text { technical success probability; 9) bubble chart; 10) } \\
\text { success indicators; 11) establishment of a prioritized } \\
\text { list of projects; 12) senior management involvement; } \\
\text { 13) analysis of selection criteria (subjective, objective, } \\
\text { qualitative or intuitive); } 14 \text { l) determination of each } \\
\text { project's cost; } 15 \text { ) urgency and seriousness. }\end{array}$ \\
\hline $\begin{array}{l}\text { Portfolio } \\
\text { Control }\end{array}$ & $\begin{array}{l}\text { 1) in-depth project planning; 2) periodic project } \\
\text { monitoring and control; 3) adjustment to users' } \\
\text { criteria; 4l adjustment criteria to strategic changes; 5) } \\
\text { performance evaluation; 6) HR competences for portfolio } \\
\text { success and performance; 7) project management } \\
\text { methodology; 8) the project management should be } \\
\text { delegated to lower levels. }\end{array}$ \\
\hline $\begin{array}{l}\text { Resources } \\
\text { Allocation }\end{array}$ & $\begin{array}{l}\text { 1) consideration of resource restrictions concerning } \\
\text { type and total of projects; } 2 \text { ) analysis between active } \\
\text { projects and new products (inserted projects); } 3 \text { l } \\
\text { allocation conducted by functional areas and other } \\
\text { stakeholders. }\end{array}$ \\
\hline
\end{tabular}

Source: authors, based on eight models identified in the literature 
U T S

e PRES S

\section{Research method}

We used an exploratory qualitative research design (Henry 2009) and conducted a single case study (Flyvbjerg 2006) in the Brazilian Medical Association (BMA), an NPO that brings together medical professionals. BMA operates in the service sector, implementing multiple scientific, social, and institutional projects through public, private, and institutional partnerships. This study focused on an association that brings together about 16,000 ophthalmologists, chosen for its status as a federal public utility entity, active management culture, and projects that reinforce commitment to its mission.

For data collection, we adopted multiple evidence sources (Eisenhardt 1989): in-depth, semi-structured interviews, with a script based on the conceptual model shown in Table 1; three-month observation of the routines, as well as the internal an external processes of the ophthalmology association; analysis of documents (constitution, bylaws, and reports from the quality management system) and records on file (financial and personnel databases and flowcharts).

We interviewed four professionals linked to the association: two were former presidents and two were service providers; all were knowledgeable about the management practices of the association being studied and were considered experts (Hair et al. 2007) in the context of medical associations. Interviews lasting between 40 and 60 minutes were conducted in August 2013. The seven PPM dimensions were briefly defined, and then the interviewees were asked questions such as: how does this develop/apply in the organization, and what prevents the organization from developing/applying it? During the interviews, additional questions were asked (when necessary) and keywords that identified the dimensions were noted. The interviews were transcribed, listened to again, and validated by the researchers, after which we proceeded to the analysis.

In analyzing the results, we initially performed data reduction and presentation, the design and pursuit of conclusions through transcription and individual reading of the interviews, as well as the notes taken during observation, in order to identify the seven PPM dimensions. Next, interview extracts about each dimension were consolidated using the content analysis method (Lee, Liebenau \& Degross 1997). We subsequently adopted the general strategy of case description and the analytical technique of suitability to the standard, including a careful reading of the speeches to verify how the PPM system was developed in the organization. Finally, we compared the procedures adopted in the case studied with the PPM dimensions of the conceptual model.

Analysis of the data collected through participant observation and analysis of documents, records on file, and excerpts from interviews led us to identify seven PPM dimensions. The converging of evidence in a triangular mode allowed data validation (Eisenhardt 1989). We sought to exemplify how in practice those elements are applied in the organization, and identify situations that deserved to be included in or excluded from the model proposition. Finally, we addressed highlighted situations in order to subsidize the model proposition adapted to the context of an NPO.

\section{Analysis of the results}

The analysis of the case study followed the conceptual model of PPM in the following dimensions: strategic alignment, resources definition, project classification, project evaluation, project selection and prioritization, portfolio control, and resources allocation. 
U T S

e PRES S

\section{Strategic alignment dimension}

To analyze this dimension, we considered the following elements: strategy definition as a precondition, strategic map, portfolio matrix, strategic planning, weighted criteria for categorization, senior management participation, and visibility (image) (De Maio, Verganti \& Corso 1994; Archer \& Ghasemzadeh 1999; Cooper, Edgett \& Kleinschmidt 2001; Rabechini, Maximiano \& Martins 2005; Kerzner 2006; PMI 2008; Rocha et al. 2009; Castro \& Carvalho 2010a).

No formal, structured methodology is used by the organization to define its strategies and compose its project portfolio. An informal dynamic does exist in which proposed projects and the history of projects already carried out are assessed, before new projects are included in the portfolio for the following year. However, this practice can be completely changed under new management, that is, with the election of a new executive board (every two years). Despite not having autonomy for decision-making, the project department is responsible for strategic planning of projects and defining the portfolio. An advisory company for the medical association's communication and marketing activities has contributed to effective strategic planning.

Annual satisfaction surveys are conducted with associates, to direct the actions of the organization, and with sponsors, who evaluate their investments and the benefits that projects provide. One respondent pointed out that "visibility, a guaranteed institutional image [...]" is a kind of return that the sponsor expects from a project. Research results have partly been used in the strategic planning of projects.

The following elements were neither identified in the practices nor mentioned in the interviews: strategic map, portfolio matrix, and weighted criteria for categorization. Furthermore, these elements have no applicability in the context of the organization because of the lack of stakeholder knowledge (Rabechini, Maximiano \& Martins 2005), or even of acceptance by the board due to a technical impossibility of analysis (Ruggeri 2011).

Clarity of strategic priorities on the part of directors and collaborators is strongly related to the scientific question (training and continuing education of associated physicians), which is the organization's core activity in accordance with its constitution and bylaws. It should be noted that, according to one interviewee, "this lack of strategic planning is common among medical societies, as they have the same profile and [it is unusual] that an organization works with strategic planning effectively."

The strategic alignment dimension of PPM presented applicability through four of the elements provided in the conceptual model, in the context of a medical association: strategy definition as a precondition, strategic planning, senior management participation, and visibility (image).

\section{Resources definition dimension}

Analysis of this dimension considered the following elements: available resources must be known, and executives and managers must participate in defining resource capacity (De Maio, Verganti \& Corso 1994; Archer \& Ghasemzadeh 1999; Cooper, Edgett \& Kleinschmidt 2001; Kerzner 2006; Castro \& Carvalho 2010a).

According to the respondents, the resources are known, and there is no participation of employees in defining the resource capacity (which is viewed as insufficient). But given their knowledge of the organization's routines and accumulated experience in various administrations, employees can contribute to reducing the possibility of a potential problem. 
U T S

e PRES S
Considering a new president takes a few months to fully understand the functioning of the organization, this transition period could otherwise (without the employees' contribution) compromise the achievement of goals set for a two-year term.

The resources definition dimension for PPM has shown applicability through both elements provided in the conceptual model, in the context of a medical association: available resources must be known, and executives and managers must participate in defining resource capacity (except for the criterion "managers").

\section{Project classification dimension}

The following elements were analyzed in this dimension: consideration of the limitation of resources available, creation of project categories, and identification of projects and ideas through brainstorming and surveys (of the market, customers, suppliers, and the literature) (De Maio, Verganti \& Corso 1994; Kerzner 2006; PMI 2008; Rocha et al. 2009; Castro \& Carvalho 2010a).

The lack of an official categorization, despite being bound by statute, and its definition of objectives defined in the campaign platforms of the presidents, can endanger the continuity of the projects, and particularly the allocation of resources. The grouping of projects into categories, according to their relevance to the medical association, would allow further analysis in the effective implementation of strategies, as well as their actual contribution to the commercial relations and expectations of members identified in the respective surveys.

An initial evaluation of project ideas is conducted by the project department. Brainstorming meetings between employees in this department, directors, and other stakeholders can define and formalize a categorization and ways of grouping the projects. Knowledge of the technical literature (industry regulatory standards) provides a basis for the meetings, composed by a group with heterogeneous knowledge of the association (directors, employees, and advisors). This practice is informal, and shared between the project department and marketing area in the preparation and presentation of the portfolio to the directors.

The project classification dimension of PPM presented applicability through two of the elements set out in the conceptual model, in the context of a medical association: creation of project categories, and identification of projects and ideas through brainstorming and surveys (of the market, customers, suppliers, and the literature) (except for the criterion "suppliers").

\section{Project evaluation dimension}

The analysis of this dimension took into consideration the following elements: relevance and risk assessment, adherence to strategic focus, feasibility study, criteria definition, quantitative analysis criteria (return on investment, net present value, internal rate of return, discounted cash flow, and decision tree), productivity index, qualitative analysis criteria (technical, cost, term, quality, safety, legality, human resources, and economic), scoring models, alignment with the third sector, and market research (De Maio, Verganti \& Corso 1994; Archer \& Ghasemzadeh 1999; Cooper, Edgett \& Kleinschmidt 2001; Rabechini, Maximiano \& Martins 2005; Kerzner 2006; PMI 2008; Rocha et al. 2009; Castro \& Carvalho 2010a).

Evaluation of projects according to strategic priorities is discussed with the executive board, but does not always take place. The list of candidate projects is prepared annually and includes information about the goals, deadlines, technical specifications, quality, and running costs. However, there is no interest in direct participation of other areas of the organization in the evaluation of these projects. They are mainly analyzed using the element of qualitative analysis 
U T S

e P R E S S

criteria, both in the evaluation of individual projects and in the annual definition of the project portfolio. A careful analysis of the feasibility study element indicates that its applicability also occurs through the qualitative analysis criteria element. This similarity also takes place with the criteria definition element, because it presents a more generic spelling.

The use and applicability of any technique or methodology for quantitative analysis criteria have not been identified, nor for productivity index and scoring models. The human resources element had real importance in the evaluation and implementation of projects. However, the alignment with the third sector element proposed in the model created by Rocha et al. (2009) has applicability to organizations that fund projects, but not in the context of who executes them - in this case, the BMA.

The project evaluation dimension for PPM presented applicability through six elements provided in the conceptual model, in the context of a medical association: relevance and risk assessment, adherence to strategic focus, feasibility study, criteria definition, qualitative analysis criteria, and market research.

\section{Projects selection and prioritization dimension}

The following elements were taken into consideration for this analysis: complex interaction among selection projects, ad hoc selection techniques, scoring models, the analytic hierarchy process (AHP) method, sensibility matrix and analysis, mission/vision/strategy operationalization, commercial success probability, technical success probability, bubble chart, indicators of success, establishment of a prioritized list of projects, involvement of senior management, analysis of selection criteria (subjective, objective, quantitative, or intuitive), determination of the cost of each project, and urgency and seriousness (De Maio, Verganti \& Corso 1994; Archer \& Ghasemzadeh 1999; Cooper, Edgett \& Kleinschmidt 2001; Rabechini, Maximiano \& Martins 2005; Kerzner 2006; PMI 2008; Rocha et al. 2009; Castro \& Carvalho 2010a).

The main criteria adopted for selecting projects is the appreciation that members attach to the association's lines of action. Based on the survey results, project expectations and priorities are assessed, as well as the need for investment in realization and communication. Projects are not placed in strict categories (strategic, financial, or organizational focus), allowing further analysis. Financial analysis is done only by project budgets. Run-time is considered in the selection and final prioritization, but not consistently, since projects that are at risk of not being completed in the specified period (annually) are also prioritized.

Overall, for selection and prioritization the association considers the history of projects within portfolios, performing individual analysis of projects, but does not verify the complex interaction among projects. Likewise, it does not adopt the following elements: ad hoc selection techniques, AHP method, sensibility matrix and analysis, or bubble chart. As in the project evaluation dimension, the scoring models element showed no applicability. On the other hand, likelihood of technical success and determination of the cost of each project were not identified, because they are already practiced in the project evaluation dimension as one of the qualitative analysis criteria.

The analysis of selection criteria (subjective, objective, quantitative, or intuitive) element proposed by Kerzner (2006) shows similarity with the qualitative analysis criteria element (if the "quantitative" criterion is excluded). On the other hand, no success indicator is defined for the projects. What is measured in the survey is the rate of satisfaction of the ophthalmologists in relation to the performance of the directors of the medical association. 
The urgency and seriousness element proposed in the model created by Rocha et al. (2009) had no applicability in the case studied for two reasons: the priority projects for the portfolio destined for sponsors did not have these characteristics; and the purpose of this element is directed to both the analysis of the generating cause of the project, which can result in damage or injury (seriousness), and the time allocated to handle or solve this question (urgency). Even if projects are deemed urgent and serious, they are performed with the association's own resources, or in some specific cases through public partnerships.

The project selection and prioritization dimension for PPM presented applicability through five of the elements provided in the conceptual model, in the context of a medical association: mission/vision/strategy operationalization, commercial success probability, establishment of a prioritized list of projects, involvement of senior management, analysis of selection criteria (subjective, objective, quantitative, or intuitive) (except for the criterion "quantitative").

\section{Portfolio control dimension}

The following elements were analyzed in this dimension: detailed planning of projects, periodic project monitoring and control, adjustment criteria for users, adjustment criteria targeted to strategic changes, performance evaluation, human resources competences for portfolio success and performance, project management methodology, and delegation of project management to lower levels (De Maio, Verganti \& Corso 1994; Archer \& Ghasemzadeh 1999; Cooper, Edgett \& Kleinschmidt 2001; Rabechini, Maximiano \& Martins 2005; PMI 2008; Castro \& Carvalho 2010a).

In the sponsorship contract, projects are listed and detailed in part with some technical specifications, delivery forecasting, and benefits to the sponsor. One respondent stated that "[...] a project needs to be very consistent, very well prepared, and then the project must be well-run [...]." After negotiating and formalizing the project portfolio by signing commercial sponsorship agreements, no exclusions or inclusions of projects occur in the contracts. Thus, adjustments to the portfolio are made without taking into account the stakeholders (sponsors), thereby leaving the adjustment criteria for users element without a practical application.

Projects are partially monitored and controlled by the projects department, through a schedule model defined by the quality management system, but there are no performance evaluations. According to one respondent, "[...] despite not having a methodology in this assessment, nor of project management, they have numbers, opinions, concrete facts [management reports] showing the success or not of each project." Another respondent emphasized the importance of project management. In his words, "projects should be managed and accounted for individually. That's the best way to have financial and accounting control of the entity."

Likewise, financial resources allocated to carry out each project are not reassessed or changed during the project. However, changes in technical specifications may occur (number of pages, paper weight, and so on for a printed publication) to match project costs to financial income. Possible changes in the forecast delivery period and institutional partnerships are related to the organization's strategic and/or political issues.

The project portfolio is managed by the project department, with the effective participation of the board of directors in the operating process for their implementation, while other departments are rarely involved. However, the response of an interviewee reinforced the importance of the involvement of other departments, stating that "time and energy are wasted, 
U T S

e PRESS

and there is a lot of reworking of things that would be unnecessary if there were in fact a much more transparent dialogue between the departments involved in each project."

The portfolio control dimension for PPM presented applicability in seven of the elements provided in the conceptual model, in the context of a medical association: detailed planning of projects, periodic project monitoring and control, adjustment criteria for users, performance evaluation, human resource competences for the portfolio success and performance, project management methodology, and delegation of project management to lower levels.

\section{Resources allocation dimension}

The elements analyzed in this dimension were: consideration of resource constraints on the type and total of projects, analysis of active projects and new products (inserted projects), and allocation made by the functional areas and other stakeholders (De Maio, Verganti \& Corso 1994; Archer \& Ghasemzadeh 1999; Cooper, Edgett \& Kleinschmidt 2001; Rabechini, Maximiano \& Martins 2005; Kerzner 2006; PMI 2008; Castro \& Carvalho 2010a).

After defining and formalizing the portfolio through contracts with sponsors, projects are neither cancelled nor added. For this reason, funds are not reallocated and departments do not compete with each other for resources. Therefore, in the case studied, political games and conflicts in allocation do not arise, as predicted by Castro \& Carvalho (2010a). Projects are centered in the project department and may involve, sporadically, other sectors or even other organizations in the execution. These criteria have already been addressed in previous dimensions.

The resources allocation dimension for PPM presented applicability through one of the elements set out in the conceptual model, in the context of a medical association: consideration of resource constraints on the type and total of projects.

\section{PPM conceptual model for NPOs}

It was evidenced at various times in the course of the interviews, as well as in the literature on management for the nonprofit context (PMI-Rio 2008; Ruggeri 2011), that the phase of capturing financial resources requires professionalism (Machado, Francisconi \& Chaerki 2007; Santos et al. 2008) and defined processes (Golini, Kalchsmidt \& Landoni 2015; Falconer 1999; Oliveira, Ross \& Altimeyer 2005; PMI-Rio 2008). Project management methodology in the nonprofit sector provides a specific step to raise funds, which should be started after the projects proposal has been completed, as this is a process that requires coordinated action with various areas of the organization (PMI-Rio 2008). This observation was also identified in several excerpts from interviews during analysis of the results, as well as the importance of the relationship with and knowledge of the activities and realities of the potential sponsor, which is also corroborated by PMI-Rio (2008).

Nevertheless, the need for NPO transparency and accountability in rendering accounts to various stakeholders (Falconer 1999; PMI-Rio 2008), especially to sponsors of projects, tends to be critical to the continuity of commercial relations. Several interviewee responses reinforced this point, including, "the best form of financial control of projects is through 'segregated accounts,' which helps to account to anyone."

In view of these reflections, a new dimension for PPM called fund-raising has been proposed, in the context of the organization studied. The elements composing this dimension are the three processes defined by PMI-Rio (2008) for fund-raising - planning fund-raising, conducting fund-raising, and signing agreements with investors - insofar 
U T S

e PRES S as they interact with the knowledge areas of project management. Another suggested element is stakeholder accountability, proposed by Falconer (1999) for the development of management of NPOs.

Importantly, of the seven dimensions in the PPM conceptual model resulting from the literature, the resources allocation dimension presented applicability through just one of the elements that comprise it (consideration of resource constraints on the type and total of projects). Therefore, the purpose of this dimension and its only element (as identified in the practices of the organization studied) were added to the resources definition dimension to create an adjusted dimension: definition and allocation of resources. New elements have also been proposed for the conceptual model, based on the need to formally apply best practices in the business relationship, to compose the new fund-raising dimension

Table 2 presents the proposition of the PPM conceptual model adapted to the context of the medical association. It arose from the conceptual model consolidated from eight models identified in the literature, and the applicability analysis of the seven dimensions that comprise it. The practices observed in the organization were also taken into consideration, as well as the highlighted situations. In addition, new elements, words, and nomenclatures have been suggested, including a new dimension (fund-raising). The constitution and bylaws of the association were taken as a reference for the application of PPM.

To highlight both the legal and practical purposes of the statutes and bylaws of the medical association studied, these documents have been added to the proposed model. They are not considered as a dimension, but must be adopted as a guiding base when applied to the seven dimensions of PPM proposals. This approach seeks to minimize political influences, as well as possible misconceptions that new directors may have around portfolio management processes, due to a lack of knowledge of the activities inherent to the entity. Using these documents as a reference in the process also helps to support the continuity of projects during management change (every two years).

Therefore, the PPM model proposed here consists of seven dimensions: that is, six dimensions originating in the comparative analysis of models identified in the literature, which were considered applicable to the medical association being studied; and a new dimension, fund-raising, that has been proposed based on the analysis of the case study. From the dimensions portrayed in the study conducted by Castro \& Carvalho (2010b), used as the basis for this study, it was also possible to propose the process for analyzing the PPM adapted to the context of a medical association, as shown in Figure 2.

The fund-raising dimension should start after the final definition of the projects, since there are no portfolio changes during negotiations with potential sponsors.

\section{Final considerations}

This study aimed to contribute to PPM within the context of NPOs, resulting in the proposal of a PPM conceptual model adapted to the specific context of this type of organization. The seven dimensions that make up the model are composed of elements that enable PPM in an NPO.

For the practice of NPO management, this study collaborates by proposing a PPM model grounded in the literature, but which is adapted to the reality of this type of organization. Therefore, it considers the guiding principles of PPM, the specific characteristics of the sector, and the environmental and cultural contexts of medical associations. By adopting their 
U T S

e PRES S

Table 2 Project portfolio management model adapted to NPOs

\begin{tabular}{|c|c|c|}
\hline \multirow[t]{4}{*}{ BASIS } & $\begin{array}{c}\text { PPM } \\
\text { DIMENSIONS }\end{array}$ & ELEMENTS \\
\hline & $\begin{array}{l}\text { Strategic } \\
\text { alignment }\end{array}$ & $\begin{array}{l}\text { 1) Strategy definition as a precondition } \\
\text { 2) Strategic planning } \\
\text { 3) Senior management participation } \\
\text { 4) Visibility (image) } \\
\text { 5) Consultation with associates }\end{array}$ \\
\hline & $\begin{array}{l}\text { Definition and } \\
\text { allocation of } \\
\text { resources }\end{array}$ & $\begin{array}{l}\text { 1) Available resources must be known and } \\
\text { limitations considered } \\
\text { 2) Executives and managers must participate in } \\
\text { defining resource capacity }\end{array}$ \\
\hline & $\begin{array}{c}\text { Project } \\
\text { classification }\end{array}$ & $\begin{array}{l}\text { 1) Creation of project categories } \\
\text { 2) Identification of projects and ideas through } \\
\text { brainstorming and surveys }\end{array}$ \\
\hline 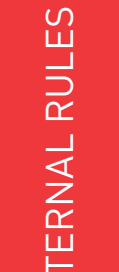 & $\begin{array}{c}\text { Project } \\
\text { evaluation }\end{array}$ & $\begin{array}{l}\text { 1) Relevance and risk assessment } \\
\text { 2) Adherence to strategic focus } \\
\text { 3) Feasibility study defining qualitative analysis } \\
\text { criteria (technical, cost, term, quality, safety, } \\
\text { legality, human resource, and economic) }\end{array}$ \\
\hline 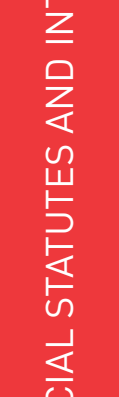 & $\begin{array}{l}\text { Project } \\
\text { selection and } \\
\text { prioritization }\end{array}$ & $\begin{array}{l}\text { 1) Operationalization of mission, vision, and strategy } \\
\text { 2) Commercial success probability } \\
\text { 3) Success indicators } \\
\text { 4) Establishment of a prioritized list of projects } \\
\text { 5) Senior management involvement } \\
\text { 6) Analysis of selection criteria (subjective, objective, } \\
\text { or intuitive) }\end{array}$ \\
\hline & $\begin{array}{l}\text { Portfolio } \\
\text { control }\end{array}$ & $\begin{array}{l}\text { 1) In-depth project planning } \\
\text { 2) Periodic project monitoring and control } \\
\text { 3) Adjustment criteria targeted to strategic and } \\
\text { political changes } \\
\text { 4) Performance evaluation } \\
\text { 5) Human resource competences for portfolio } \\
\text { success and performance } \\
\text { 6) Project management methodology } \\
\text { 7) Delegation of project management to lower levels }\end{array}$ \\
\hline & Fund-raising & $\begin{array}{l}\text { 1) Fund-raising planning } \\
\text { 2) Fund-raising implementation } \\
\text { 3) Signing of agreements with investors } \\
\text { 4) Stakeholder accountability }\end{array}$ \\
\hline
\end{tabular}

Source: Authors. 
U T S

e PRES S

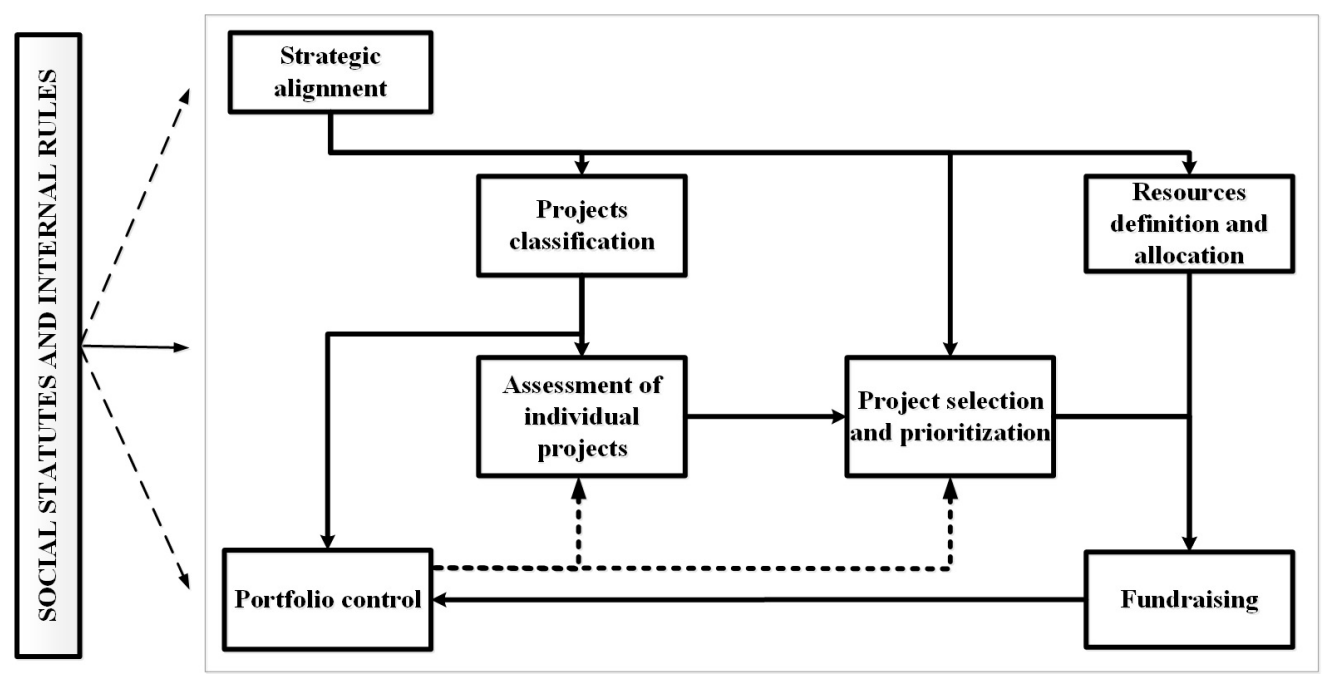

Figure 2 Dimensions for the analysis of PPM adapted for NPOs

Source: authors, inspired by Castro \& Carvalho (2010b)

statutes as a guiding basis for portfolio management, the model can contribute both to the implementation and definition of strategies.

The proposed model offers elements for directors, managers, and advisors in the nonprofit sector, which can be used as drivers for PPM practices, as well as for the deployment of strategic actions, missions, visions, and goals. These associations have similarities to one another in terms of types of projects, financial fund-raising modes, governance of statutes, compliance with technical standards, and regular changes in boards of directors.

As an academic contribution, this study aimed to investigate PPM practices - since the theoretical and empirical studies under this approach are considered incipient - in the NPO context and especially in medical associations, and to propose a model adapted to this reality. The PPM conceptual model presented here also contributes to academic studies insofar as it brings together the characteristics of the main models identified in the literature.

The study has some methodological limitations. Regarding respondents, if more directors had participated they may have contributed with other information that could eventually lead to the analysis of other elements. Another researcher could define a different way of presenting the results, and identify further additions or deletions of words and elements in the model proposition. However, through the triangulation of data, we sought to suppress potential conflicts of interest in directors who were interviewed, and in the analysis and interpretation of results by researchers.

For future research, an empirical study of the medical association studied is recommended in order to verify the adherence of the proposed model, and the way it has developed and contributed to PPM. The research strategy that could be adopted for this study would be that of "research-action". The model can also be tested in other medical organizations and different professional associations. In addition, quantitative studies could assess the dimensions and elements proposed in the PPM model that resulted from this study, to verify their applicability in other NPOs. 


\section{About the authors}

Fabrício Martins Lacerda, PhD Student, Management Graduate Program, UNINOVE Universidade Nove de Julho, São Paulo, Brazil. Master in Business Administration with emphasis on Project Management, UNINOVE.

Cristina Dai Prá Martens, Professor, Management Graduate Program, UNINOVE -

Universidade Nove de Julho, São Paulo, Brazil. PhD in Business Administration - Information Systems and Decision Support at PPGA/EA/UFRGS (2009). Post-doctoral year at CERAG/ UPMF - Université Pierre Mendès-France (Grenoble, France - 2010).

Henrique M R de Freitas, Professor, Management Graduate Program, UNINOVE Universidade Nove de Julho, São Paulo, Brazil. PhD in MIS from UPMF / ESA (Grenoble, France, 1990-1993), post-doctoral year at the University of Baltimore (MD, USA, 19971998), and the UPMF (Grenoble, France, 2003-2004) (2012).

\section{Acknowledgments}

This research had financial support from Brazilian institutions: CNPq - National Council for Scientific and Technological Development, CAPES - Coordination for the Improvement of Higher Education Personnel, and FAP/UNINOVE.

\section{References}

Albuquerque, A.C.C. 2006, Terceiro setor: história e gestão de organizaçôes, 2nd edn, Summus, São Paulo, p. 152.

Almeida, N. de O. \& Almeida, F.A. 2013, Metodologia de gerenciamento de portfólio: teoria e prática, 1st edn, Brasport, Rio de Janeiro, p. 234.

Antunes, P.H., Loos, M.J. \& Miguel, P.A. 2012, 'Portfólio no desenvolvimento de novos produtos: uma análise das publicações em periódicos nacionais', Revista de Gestão e Projetos, vol. 3, no. 1, pp. 50-71. http://dx.doi.org/10.5585/gep.v3i1.49

Archer, N.P. \& Ghasemzadeh, F. 1999, 'An integrated framework for project portfolio selection', International Journal of Project Management, vol. 17, no. 4, pp. 207-16. http://dx.doi.org/10.1016/S0263$\underline{7863(98) 00032-5}$

Borges, C.N. \& Costa Filho, B.A. 2010, 'Terceiro setor e o gerenciamento de projetos: análise de uma ferramenta estratégica', Anais, XIII SEMEAD - Seminários em Administração, São Paulo, pp. 1-12.

Castro, H.G. de \& Carvalho, M.M. de 2010a, 'Gerenciamento do portfólio de projetos: um estudo exploratório', Gestão Ė Produção, vol. 17, no. 2, pp. 283-96. http://dx.doi.org/10.1590/S0104-530X2010000200006

Castro, H.G. de \& Carvalho, M.M. de 2010b, 'Gerenciamento do portfólio de projetos (PPM): estudos de caso', Revista Produção, vol. 20, no. 3, pp. 303-21. http://dx.doi.org/10.1590/s010365132010005000044

Cooper, R.G., Edgett, S.J. \& Kleinschmidt, E.J. 2001, 'Portfolio management: fundamental to new product success', Product Development Institute, vol. 12, pp. 1-33.

Corrion, R.M. 2000, 'Organizações privadas sem fins lucrativos: a participação do mercado no terceiro setor', Tempo Social, vol. 12, no. 2, pp. 237-55. http://dx.doi.org/10.1590/S0103-20702000000200015

De Maio, A., Verganti, R. \& Corso, M. 1994, 'A multi-project management framework for new product development', European Journal of Operational Research, vol. 78, no. 2, pp. 178-91. http://dx.doi. org/10.1016/0377-2217(94)90381-6 
U T S

e PRES S
Eisenhardt, K.M. 1989, 'Building theories from case study research', Academy of Management Review, vol. 14, no. 4, pp. 532-50. http://dx.doi.org/10.5465/AMR.1989.4308385 and http://dx.doi. org/10.2307/258557

Falconer, A.P. 1999, A promessa do terceiro setor, Centro de Estudos em Administração do Terceiro Setor, Universidade de São Paulo.

Fischer, R.M. 2002, O desafio da colaboração: práticas de responsabilidade social entre empresas e terceiro setor, 1st edn, Gente, São Paulo, p. 172.

Flyvbjerg, B. 2006, 'Five misunderstandings about case-study research', Qualitative Inquiry, vol. 12, no. 2, pp. 219-45. http://dx.doi.org/10.1177/1077800405284363

Golini, R., Kalchschmidt, M. \& Landoni, P. 2015, 'Adoption of project management practices: the impact on international development projects of non-governmental organizations', International Journal of Project Management, vol. 33, pp. 650-63. http://dx.doi.org/10.1016/j.ijproman.2014.09.006

Gutiérrez, E. \& Magnusson, M. 2014, 'Dealing with legitimacy: a key challenge for project portfolio management decision makers', International Journal of Project Management, vol. 32, pp. 30-39. http:// dx.doi.org/10.1016/j.ijproman.2013.01.002

Hair, J.F.J., Babin, B., Money, A.H. \& Samouel, P. 2007, 'Plano de pesquisa básica', in L.B. Ribeiro (ed.), Fundamentos de métodos de pesquisa em administração, 1st edn, Bookman, Porto Alegre, pp. 84-96.

Heinzen, D.A. de M., Rosseto, C.R. \& Altoff, J.R. 2013, 'Identificação e categorização dos stakeholders de uma organização do terceiro setor', Revista Ibero-Americana de Estratégia, vol. 12, no. 1, pp. 154-80. http://dx.doi.org/10.5585/riae.v12i1.1938

Henry, G.T. 2009, 'Practical sampling', in L. Bickman \& D.J. Rog (eds), Handbook of applied social research methods, 2nd edn, SAGE, Thousand Oaks, pp. 77-105. http://dx.doi.org/10.4135/9781483348858.n3

Kaplan, R.S. 2001, 'Strategic performance measurement and management in nonprofit organizations', Nonprofit Management and Leadership, vol. 11, no. 3, 353-70. http://dx.doi.org/10.1002/nml.11308

Kerzner, H. 2006, Gestão de projetos: as melhores práticas, 2nd edn, Bookman, Porto Alegre, p. 824.

Lee, A.S., Liebenau, J. \& Degross, J.I. 1997, Information systems and qualitative research, Chapman \& Hall, IFIP, New York.

Machado, A.C.M., Francisconi, K. \& Chaerki, S.F. 2007, 'Mapeando a abordagem estratégica em publicações acadêmicas sobre o terceiro setor', Revista Gerenciais, vol. 6, no. 2, pp. 127-36.

Marcovitch, J. 1997, Da exclusão à coesão social: profissionalização do terceiro setor, Paz e Terra, Rio de Janeiro.

Moxham, C. 2014, 'Understanding third sector performance measurement system design: a literature review', International Journal of Productivity and Performance Management, vol. 63, no. 6, pp. 704-26. http://dx.doi.org/10.1108/IJPPM-08-2013-0143

Oliveira, B., Ross, E.S. \& Altimeyer, H.Y. 2005, 'Proposta de um modelo de planejamento estratégico para instituições sem fins lucrativos', Revista da FAE, vol. 8, no. 1, pp. 69-80.

Padovani, M., Carvalho, M.M. de \& Muscat, A.R.N. 2010, 'Seleção e alocação de recursos em portfólio de projetos: estudo de caso no setor químico', Gestão छ Produção, vol. 17, no. 1, pp. 157-80. http://dx.doi. org/10.1590/S0104-530X2010000100013

PMI 2008, The Standard for Portfolio Management, 2nd edn, Project Management Institute, Newton Square, p. 146. 
Rabechini, R. Jr., Maximiano, A.C.A. \& Martins, V.A. 2005, 'A adoção de gerenciamento de portfólio como uma alternativa gerencial: o caso de uma empresa prestadora de serviço de interconexão eletrônica', Revista Produção, vol. 15, no. 3, pp. 416-33. http://dx.doi.org/10.1590/s0103-65132005000300011

Rocha, F.M., Treinta, F.T., Coutinho, G.F.F. \& Farias, J.R.F. 2009, ‘Gerenciamento de Portfólio: proposta de um modelo adaptado ao Terceiro Setor', Anais, XVI SIMPEP, Bauru, pp. 1-12.

Ruggeri, R.G. 2011, Gerenciamento de projetos no terceiro setor, 1st edn, Brasport, Rio de Janeiro, p. 117.

Santos, N.C. dos, Sublaban, C.S.Y., Neto, M.S., Giuliani, A.C. \& Spers, V.R.E. 2008, 'Captação de recursos financeiros em organizações sem fins lucrativos: a utilização de indicadores de gestão para os doadores e beneficiários dos projetos sociais', REGE Rev. Gest, vol. 15 (especial), pp. 75-91.

Soares, A.C.A.A. \& Melo, M.C. de O.L. 2010, 'Gestão estratégica do terceiro setor: uma prática social?’, Revista de Gestão USP, vol. 17, no. 1, pp. 1-11. http://dx.doi.org/10.5700/rege383

Unger, B.N. 2015, 'Corporate innovation culture and dimensions of project portfolio success: the moderating role of national culture', Project Management Journal, vol. 45, no. 6, pp. 38-57. http://dx.doi. org/10.1002/pmj.21458

Xavier, C.M. da S. (ed.) 2008, Metodologia de gerenciamento de projetos no terceiro setor: uma estratégia para a condução de projetos, Project Management Institute - Rio de Janeiro, Brasport, Rio de Janeiro, p. 175. 